\title{
MEWUJUDKAN APARATUR PEMERINTAH DAERAH YANG PROFESIONAL DALAM MENDORONG PERCEPATAN PENINGKATAN KUALITAS PELAYANAN PUBLIK MELALUI DINAS PERTANAHAN DAN TATA RUANG KABUPATEN SUKABUMI
}

\author{
M. Rendi Aridhayandi ${ }^{1}$, Asep Sobur ${ }^{2}$, Yuyun Yulianah ${ }^{3}$, Mumuh M. Rozi ${ }^{4}$
}

\begin{abstract}
ABSTRAK
Tanah adalah karunia Tuhan Yang Maha Kuasa yang harus dikelola sebaik-baiknya demi kemakmuran dan kesejahteraan rakyat secara berkeadilan dan berkelanjutan. Untuk mengelola tanah, maka diperlukan aturan main dalam hal menguasai dan menggunakannya yang bersifat adil, suatu potensi dan menjaga kelestarian lingkungannya. UUD 1945 Pasal 33 ayat (3) yang menyebutkan Bumi dan air dan kekayaan alam yang terkandung didalamnya dikuasai oleh negara dan dipergunakan untuk sebesar-besar kemakmuran rakyat. Kabupaten Sukabumi harus mendaya gunakan dan memaksimalkan potensi yang dimiliki sehingga menjadi daerah yang tangguh dan kompetitif, yaitu dengan kebijakan pertanahan dan tata ruang yang mempunyai tujuan menciptakan kesejahteraan masyarakat khususnya mengoptimalkan untuk kesejahteraan masyarakat lokal. Dengan demikian diperlukan aparatur Pemerintah Daerah yang profesional dalam mendorong percepatan peningkatan kualitas pelayanan publik melalui dinas pertanahan dan tata ruang Kabupaten Sukabumi.
\end{abstract}

Kata kunci: Kabupaten Sukabumi; Pemerintah Daerah; Pertanahan; Tata Ruang.

\begin{abstract}
The land is the gift of God Almighty that must be managed as well as possible for the prosperity and welfare of the people in a just and sustainable manner. To manage land, it is necessary to play rules in terms of controlling and using it that is fair, a potential and preserving the environment. The 1945 Constitution Article 33 paragraph (3) which states that the Earth and water and natural resources contained therein are controlled by the state and used for the greatest prosperity of the people. Sukabumi Regency must utilize and maximize its potential so that it becomes a tough and competitive region, with land and spatial planning policies that have the goal of creating community welfare, especially optimizing for the welfare of the local community. Thus the Regional Government apparatuses are needed to be professional in encouraging the acceleration of the improvement of the quality of public services through the land and spatial services department of Sukabumi Regency.
\end{abstract}

Keywords: Sukabumi Regency; Regional Government; Land; Spatial.

Dosen Program Studi Ilmu Hukum, Fakultas Hukum, Universitas Suryakancana, Email: mrendiaridhayandi@unsur.ac.id

ASN Kab. Sukabumi, Alumni Pascasarjana Ilmu Hukum Universitas Suryakancana, Cianjur.

Dosen Fakultas Hukum, Universitas Suryakancana, Cianjur.

Dosen Fakultas Hukum, Universitas Suryakancana, Cianjur. 


\section{PENDAHULUAN}

\subsection{Latar Belakang}

Pemerintah Kabupaten Sukabumi pada tanggal 09 Desember 2015 telah melaksanakan Pemilukada serentak sebagaimana telah ditentukan dalam Undang-Undang Nomor 15 Tahun 2015. Dalam Pemilukada tersebut telah terpilih secara jujur, transparan, adil dan demokratis Marwan Hamami sebagai Bupati Sukabumi dan Adjo Sardjono sebagai Wakil Bupati Sukabumi untuk periode masa jabatan Tahun 2016-2021. Selanjutnya Bupati dan Wakil Bupati terpilih telah dilantik pada tanggal 17 Februari 2016 oleh Gubernur Jawa Barat, di Bandung. ${ }^{5}$ Dengan demikian Bupati dan Wakil Bupati berhak untuk memimpin Kabupaten Sukabumi dengan segala kebijakannya, termasuk tentang Tata Ruang Wilayah Kabupaten Sukabumi.

Pasal 2 Peraturan Daerah Kabupaten Sukabumi Nomor 22 Tahun 2012 tentang Rencana Tata Ruang Wilayah Kabupaten Sukabumi Tahun 2012-2032 ayat (1) menyebutkan lingkup wilayah RTRW Kabupaten Sukabumi meliputi batas yang ditentukan berdasarkan aspek administratif mencakup: Wilayah daratan seluas 416.173 (empat ratus enam belas ribu seratus tujuh puluh tiga) hektar. Hal ini menunjukkan betapa luasnya potensi wilayah yang dimiliki oleh Kabupaten Sukabumi. Hal ini menjadi dasar bahwa wilayah pertanahan dan tata kota memiliki peran yang sentral. Bagaimana tidak, jika potensi luas wilayah Kabupaten Sukabumi tidak dikelola dengan baik, bukannya menjadi keunggulan justru menjadi sebaliknya. Agar potensi luas wilayah Kabupaten Sukabumi ini benar terwujud menjadi keunggulan. Pemerintah Kabupaten Sukabumi membentuk Dinas Pertanahan dan Tata Ruang guna mengoptimalkan potensi yang ada serta mengatasi berbagai potensi masalah yang akan dihadapi.

Dengan demikian, Kabupaten Sukabumi ingin menyelaraskan Das Saen dan Das Sollen (suatu harapan dan suatu kenyataan) yang ada. Jika Lawrence M. Friedman menyatakan bahwa terdapat tiga komponen utama yang dimiliki sistem hukum adalah legal structure, legal substance, and legal culture. Dimana ketiga komponen tersebut saling menentukan satu sama lainnya, demikian juga saling berpengaruh satu sama lainnya. ${ }^{6}$ Begitu pula suatu pemerintahan

5 Dikutip dalam Pendahuluan Peraturan Daerah Kabupaten Sukabumi Nomor 4 Tahun 2016 tentang Rencana Pembangunan Jangka Menengah Daerah Kabupaten Sukabumi Tahun 2016-2021, hlm. 2-3.

6 Lawrence M. Friedman, American Law, (New York-London), W.W. Norton \& Company, 1984, hlm. 5-6. 
yang harus memiliki kerjasama di semua komponen. Yaitu pemerintah (legal structure), hukum/aturan (legal substance), dan peran serta masyarakat (legal culture).

Oleh karena itu, menarik bagi penulis untuk dikaji tentang "Mewujudkan Aparatur Pemerintah Daerah Yang Profesional Dalam Mendorong Percepatan Peningkatan Kualitas Pelayanan Publik Melalui Dinas Pertanahan Dan Tata Ruang Kabupaten SukabumI".

Oleh karena itu rumusan masalah yang dapat dikaji dalam tulisan ini adalah sebagai berikut:

1. Apa permasalahan dalam kualitas pelayanan publik di bidang pertanahan dan tata ruang Kabupaten Sukabumi?

2. Bagaimana upaya mengatasi potensi permasalahan kualitas pelayanan publik di bidang pertanahan dan tata ruang Kabupaten Sukabumi?

\section{METODE PENELITIAN}

Berdasarkan pembahasan di atas, Penulis melaksanakan pendekatan yuridis normatif dalam melaksanakan penelitian ini sebagai tumpuan dalam penelitian adalah data sekunder. Pendekatan yuridis normatif sebuah pendekatan melalui proses pengujian atau menganalisis data sekunder yang berupa bahan-bahan hukum sekunder dengan memahami hukum sebagai aturan atau norma positif di dalam perundang-undangan yang berlaku, jadi penelitian ini dipahami sebagai penelitian kepustakaan, yaitu penelitian terhadap bahan sekunder. ${ }^{7}$

\section{HASIL PENELITIAN DAN PEMBAHASAN}

Aparatur Pemerintah Daerah dituntut untuk Profesional, yaitu salah satunya tentang kualitas pelayanan publik di bidang pertanahan dan tata ruang Kabupaten Sukabumi yang didalamnya memerlukan percepatan, dengan beberapa hal yang perlu diperhatikan:

\subsection{Kondisi Pertanahan dan Tata Ruang di Kabupaten Sukabumi.}

Tanah adalah karunia Tuhan YME yang harus dikelola sebaik-baiknya. Pengelolaan yang baik bertujuan demi kemakmuran dan kesejahteraan rakyat secara berkeadilan dan berkelanjutan. Untuk mengelola tanah, maka diperlukan aturan main dalam hal menguasai dan

Soerjono Soekanto, Penelitian Hukum Normatif Suatu Tinjauan Singkat, Raja Grafindo, Jakarta, 1985, hlm. 15. 
menggunakannya yang bersifat adil, suatu potensi dan menjaga kelestarian lingkungannya. ${ }^{8}$ Kabupaten Sukabumi telah memiliki Peraturan Daerah Kabupaten Sukabumi Nomor 22 Tahun 2012 tentang Rencana Tata Ruang Wilayah Kabupaten Sukabumi Tahun 2012-2032, selanjutnya Peraturan Daerah Kabupaten Sukabumi Nomor 4 Tahun 2016 tentang Rencana Pembangunan Jangka Menengah Daerah Kabupaten Sukabumi Tahun 2016-2021. Dari peraturan daerah yang telah disebutkan di atas, semestinya Road Map Kabupaten Sukabumi, khususnya dibidang pertanahan dan tata ruang sudah memiliki aturan yang jelas. Sebagai contoh dalam Paragraf 1 Kebijakan Penataan Ruang Pasal 3 Peraturan Daerah Kabupaten Sukabumi Nomor 22 Tahun 2012 Tentang Rencana Tata Ruang Wilayah Kabupaten Sukabumi Tahun 2012-2032 menyebutkan Kebijakan Penataan Ruang Kabupaten meliputi:

1. pencapaian luas kawasan lindung hutan dan non hutan;

2. pengembangan sentra agribisnis berorientasi sistem agropolitan dan minapolitan;

3. pengembangan wisata budaya, wisata alam, dan wisata buatan memanfaatkan potensi alam dan memperhatikan kelestarian lingkungan hidup dan budaya;

4. pengembangan kawasan peruntukan industri bertumpu pada potensi sumber daya lokal;

5. pengembangan sistem pusat kegiatan dan peningkatan sistem pelayanan sarana dan prasarana wilayah secara berjenjang dan sinergis; dan

6. peningkatan fungsi kawasan untuk pertahanan dan keamanan negara.

Namun tidak menutup kemungkinan dalam pelaksanan bidang pertanahan dan tata ruang perlu adanya peninjauan ulang, sebagaimana yang telah tertuang dalam Bab XIII tentang Ketentuan Lain-lain Pasal 207 ayat (2) menyebutkan dalam kondisi lingkungan strategis tertentu yang berkaitan dengan bencana alam skala besar dan/atau perubahan batas tereitorial provinsi yang di tetapkan dengan peraturan perundang-undangan, RTRW Kabupaten dapat ditinjau kembali lebih dari 1 (satu) kali dalam 5 (lima) tahun. Ayat (3) Peninjauan kembali sebagaimana dimaksud pada ayat (2) dapat dilakukan apabila terjadi perubahan kebijakan nasional dan strategi yang mempengaruhi pemanfaatan ruang Kabupaten dan/atau dinamika internal Kabupaten. Ayat (4) Peninjauan kembali RTRW dilarang dilakukan dengan tujuan pembenaran terhadap penyimpangan pemanfaatan ruang wilayah.

Pada akhirnya aturan buatan manusia yang perlu dengan konsisten dan konsekuen dalam melaksanakannya. Baik pembuat aturan, pelaksana aturan, penegak aturan dan masyarakat.

8 Mulyono Sadyohutomo, Tata Guna Tanah dan Penyerasian Tata Ruang, Pustaka Pelajar, Yogyakarta, 2016, hlm. 1. 
memang perlu adanya tinjauan/penelitian lebih lanjut tentang Kondisi Pertanahan dan Tata Ruang di Kabupaten Sukabumi. Apakah implementasi penggunaan tanah dan tata ruang sudah sesuai dengan Peraturan Daerah Kabupaten Sukabumi Nomor 22 Tahun 2012 tentang Rencana Tata Ruang Wilayah Kabupaten Sukabumi Tahun 2012-2032? Atau analisis lainnya yang berkaitan dengan ruang lingkup pertanahan dan tata ruang. Namun, yang paling penting dari tinjauan umum tentang pertanahan dan tata ruang di Kabupaten Sukabumi adalah mengenai kebijakan yang tepat dalam mengatur, memanfaatkan dan melestarikan suatu potensi yang ada. Menurut Carl J. Fredrick berpendapat bahwa kebijakan sebagai "serangkaian tindakan yang diusulkan oleh seseorang, kelompok atau pemerintah dalam suatu lingkungan tertentu dengan menunjukkan hambatan dan kesempatan terhadap pelaksanaan usulan kebijakan tersebut dalam rangka mencapai tujuan tertentu. ${ }^{9}$ Selanjutnya, Safri Nugraha, dkk mengemukakan empat ciri dari suatu kebijakan publik, yaitu: ${ }^{10}$

1. kebijakan adalah suatu tindakan pemerintah yang mempunyai tujuan menciptakan kesejahteraan masyarakat;

2. kebijakan dibuat melalui tahap-tahap yang sistematis sehingga semua variabel pokok dari semua permasalahan yang akan dipecahkan tercakup;

3. kebijakan harus dapat dilaksanakan oleh (unit) organisasi pelaksana.

4. Kebijakan perlu dievaluasi sehingga diketahui berhasil tidaknya dalam menyelesaikan masalah.

\section{Keadaan Pegawai, Keuangan dan Sarana Prasarana.}

Suatu Pemerintahan sehebat, secerdas dan setangguh pemimpin seperti apapun tidak akan maksimal jika tidak didukung oleh pegawai yang hebatm cerdas dan tangguh. Oleh karena itu harus super team dalam menjalankan suatu pemerintahan. Selain itu juga ketersediaan anggaran/keuangan dan sarana prasarana pendukung.

Sebagai contoh, dalam RPJMD Kabupaten Sukabumi Tahun 2016-2021 adalah rencana pembangunan tahap ketiga dari pelaksanaan RPJPD 2005-2025. Oleh sebab itu, penyusunan RPJMD selain memuat visi, misi, dan program juga berpedoman kepada RPJPD Kabupaten Sukabumi 2005-2025. Dengan kata lain, menyelaraskan pencapaian visi, misi, tujuan, sasaran, kebijakan, strategi dan program pembangunan jangka menengah daerah dengan visi, misi, arah kebijakan pembangunan jangka panjang daerah.

\footnotetext{
9 A.M Yunus Wahid, Pengantar Hukum Tata Ruang, Kencana Prenada Group, Jakarta, 2014, hlm. 142.

10 Safri Nugraha, dkk, Hukum Administrasi Negara, Editor: Sri Mamudi, Center forLaw and Good Governance Studies (CLGS) Fakultas Hukum Universitas Indonesia, Jakarta, 2007, hlm. 203-206.
} 
Secara umum, arah pembangunan jangka panjang Kabupaten Sukabumi 2005-2025 pada dasarnya dalam rangka pencapaian sasaran peningkatan kualitas Sumber Daya Manusia sehingga memiliki tingkat kesejahteraan yang memadai yakni minimal mencapai angka IPM sebesar 78 pada tahun 2025 (IPM Jawa Barat tahun 2025 diproyeksikan mencapai 82,82). Secara bertahap, target IPM Kabupaten Sukabumi yang ingin dicapai pada akhir RPJM ke-1 (2006-2010) mencapai IPM 70,87, pada akhir RPJM ke-2 (2011-2015) minimal mencapai IPM 72,82 (IPM Jawa Barat diproyeksikan mencapai 80,81), pada akhir RPJM ke-3 (20162020) minimal mencapai IPM 75,13 (IPM Jawa Barat diproyeksikan mencapai berkisar 81), dan pada akhir RPJM ke-2 (2021-2025) minimal mencapai IPM 77,33 (IPM Jawa Barat diproyeksikan mencapai 82,82). (target IPM pada RPJPD Kabupaten Sukabumi merupakan perhitungan metode lama).

Sasaran pokok sebagaimana diamanatkan dalam RPJPD dijabarkan dalam program pembangunan daerah sesuai dengan arah kebijakan pembangunan daerah periode 5 (lima) tahun berkenaan. Suatu program pembangunan daerah harus menjabarkan dengan baik sasaran-sasaran pokok sebagaimana diamanatkan dalam RPJPD dan tujuan dan sasaran dari visi dan misi rencana pembangunan 5 (lima) tahun. Untuk itu, diperlukan identifikasi berbagai permasalahan pembangunan daerah untuk menjabarkan pencapaian sasaran pokok sebagaimana diamanatkan dalam RPJPD dan mencapai tujuan dan sasaran RPJMD.

Dengan demikian bagaimana mungkin target IPM dapat terpenuhi jika keadaan pegawai, keuangan dan sarana prasarana tidak memadai. Terutama untuk Dinas Pertanahan dan Tata Ruang yang menjadi sentral dari suatu pemerintahan. Karena dari dinas inilah rekomendasi pertanahan serta aturan tata ruang Kabupaten Sukabumi ditentukan, bagaimana Kabupaten Sukabumi dapat mewujudkan Visi Misi jika tidak dimulai dari tata kebijakan pertanahan dan penataan ruang.

\section{Fungsi Aparatur Pemerintah Daerah Terkait Pertanahan dan Tata Ruang.}

Sesuai dengan Pasal 172 Undang-Undang No. 23 tahun 2014 tentang Pemerintahan Daerah, Perangkat Daerah menyusun rencana strategis dengan berpedoman pada RPJMD Kabupaten Sukabumi Tahun 2016-2021. Rencana strategis Perangkat Daerah tersebut memuat tujuan, sasaran, program, dan kegiatan pembangunan dalam rangka pelaksanaan Urusan Pemerintahan Wajib dan/atau Urusan Pemerintahan Pilihan sesuai dengan tugas dan fungsi setiap Perangkat Daerah. 
Pencapaian sasaran, program, dan kegiatan pembangunan dalam rencana strategis Perangkat Daerah sebagaimana dimaksud diselaraskan dengan pencapaian sasaran, program, dan kegiatan pembangunan yang ditetapkan dalam rencana strategis kementerian atau lembaga pemerintah nonkementerian untuk tercapainya sasaran pembangunan nasional.

Perumusan tujuan dan sasaran dari visi dan misi kepala daerah dan wakil kepala daerah menjadi landasan perumusan visi, misi, tujuan dan sasaran Renstra PD untuk periode 5 (lima) tahun. Kuatnya hubungan kedua lembaga antara kepala daerah dan Perangkat Daerah dalam perumusan tujuan dan sasaran untuk mewujudkan visi dan misi, dapat di jelaskan dalam bagan berikut ini:

\section{Gambar $^{11}$}

Hubungan Kinerja Pembangunan Daerah.

Terkait perangkat daerah di bidang pertanahan dan tata ruang. Kepala Dinas Pertanahan dan Tata Ruang landasan merumusan visi, misi, tujuan dan sasaran Renstra PD untuk periode 5 (lima) tahun, kemudian merumusan tujuan dan sasaran untuk mewujudkan visi dan misi, dan untuk mewujudkannya dilakukan dengan program kegiatan prioritas di bidang pertanahan dan tata ruang. Semua hal tersebut akan tertuang di dalam Renstra SKPD.

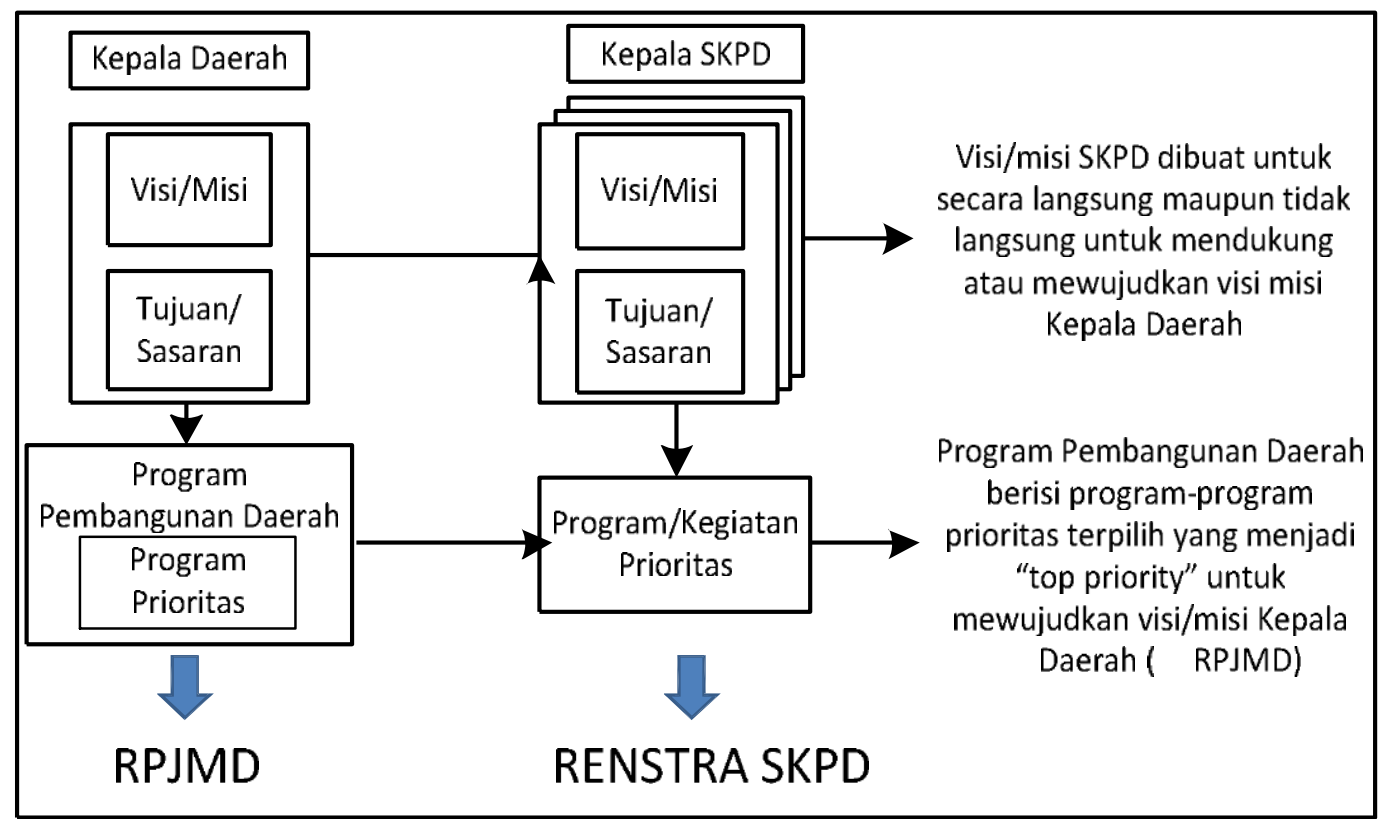

11 Ibid,. hlm. 205. 


\section{Visi Kabupaten Sukabumi.}

Terwujudnya Kabupaten Sukabumi Yang Religius dan Mandiri.

Kesejahteraan dan kemajuan masyarakat kabupaten Sukabumi sangat dipengaruhi oleh sikap keberagamaan (religius) dan kemandirian. Religius = Komitmen terhadap agama yang dianutnya yang tercermin dalam tiga aspek utama yaitu keimanan, ilmu dan amal. Implikasi:

a. Agama sebagai pedoman dan landasan berpijak bagi setiap perilaku berbangsa dan bernegara, baik dari masyarakat luas maupun bagi pemerintah atau birokrasi.

b. Tumbuhnya mental atau karakter yang sehat dan dinamis.

Kemandirian = Keyakinan akan kemampuan dan segenap potensi yang dimiliki. Implikasi: Kabupaten Sukabumi bisa menjadi daerah yang tangguh dan kompetitif ditengahtengah persaingan yang semakin komplek.

\section{Misi Kabupaten Sukabumi.}

a. Meningkatkan kemandirian ekonomi masyarakat berbasis ekonomi lokal melalui bidang agribisnis, pariwisata dan industri yang berwawasan.

Pembangunan ekonomi masyarakat melalui agribisnis, pariwisata, dan industri. Kemandirian ekonomi diukur dari peningkatan kesejahteraan daya beli dan laju pertumbuhan ekonomi. Pembangunan ekonomi harus mampu menurunkan jumlah penduduk miskin, pengangguran, serta memperkecil tingkat kesenjangan.

b. Mewujudkan Sumber Daya Manusia yang berdaya saing dan religius. Masyarakat Kabupaten Sukabumi yang agamis, berahlak mulia, sehat, cerdas, bermoral, memiliki semangat kemandirian, serta siap menghadapi berbagai tantangan kehidupan.

c. Mewujudkan tata kelola pemerintahan yang bersih dan profesional.

Pemerintah yang bermutu dan akuntabel, handal dan terpercaya dalam pelayanan yang ditopang oleh aparatur profesional, sistem yang modern, berbasis IPTEK menuju tata kelola pemerintahan yang baik (Good Governance) serta menerapkan Paten di tinggkat Kecamatan

d. Optimalisasi pelayanan kesehatan, pendidikan, dan infrastruktur daerah.

Pembangunan pelayanan kesehatan dan pendidikan yang bermutu serta pembangunan infrastruktur dasar yang dapat memadai, serta didukung oleh tersedianya infrastruktur yang mampu meningkatkan konektivitas antar wilayah dan pertumbuhan ekonomi. 


\section{Agenda Prioritas Pembangunan.}

Adapun agenda dari prioritas pembangunan akan diuraikan sebagai berikut:

a. Perluasan kesempatan kerja dan kesempatan usaha;

b. Pembangunan infrastruktur dan pembangunan pariwisata Sukabumi menjadi destinasi wisata duniadan optimalisasi pemanfaatan kawasan strategis Kabupaten (KSK) yang berwawasan lingkungan;

c. peningkatan efektivitas dan profesionalisme aparatur pemerintah serta membangun budaya birokrat pelayan masyarakat;

d. peningkatan kemampuan daerah dalam menciptakan kesejahteraan masyarakat;

e. peningkatan kualitas sumber daya masyarakat, melalui layanan pendidikan, kesehatan, sosial, agama, budaya pemuda.

\section{Implementasi Visi, Misi Kabupaten Sukabumi Berelevansi dengan Pertanahan dan Tata Ruang.}

Pertumbuhan dan perkembangan pembangunan di segala bidang selama ini dirasakan telah menampakkan hasil, terutama pada masa sebelum dan menjelang era reformasi, tetapi juga di sisi lain melahirkan persoalan-persoalan baru yang semakin rumit, sehingga timbul konsekuensi terjadinya perubahan yang besar dalam masyarakat. ${ }^{12}$ Kompleksitas pembangunan tersebut di antaranya pertumbuhan dan perkembangan sarana dan prasarana daerah, terutama semenjak dihembuskannya konsep otonomi daerah. Kebutuhan akan sarana dan prasarana tersebut diantaranya adalah perumahan, perkantoran, perdagangan, industri, pelayanan jasa, pariwisata, dan lain-lain. ${ }^{13}$

Pesatnya serta keragaman pembangunan yang terjadi, ternyata dihadapkan pada persoalan-persoalan seperti, yang berkaitan dengan pemanfaatan lahan: ${ }^{14}$

a. Terbatasnya lahan yang tersedia dengan berbagai fungsi peruntukan;

b. Pemanfaatan dan pengelolaan lahan serta pola tata ruang yang belum sepenuhnya dilaksanakan dengan terpadu dan menyeluruh;

c. Penggunaan lahan seringkali terjadi penyimpangan dari peruntukannya;

\footnotetext{
12 Juniarso Ridwan dan Achmad Sodik, Hukum Tata Ruang (dalam Konsep Kebijakan Otonomi Daerah), Nuansa, Bandung, 2013, hlm. 34.

13 Ibid,.

14 Ibid., hlm. 34-35.
} 
d. Persaingan mendapatkan lokasi lahan yang telah didukung atau yang berdekatan dengan berbagai fasilitas perkotaan, sebagai akibat pertumbuhan dan perkembangan kota;

e. Masih rendahnya kesadaran hukum masyarakat terhadap kepatutan atas kewajiban sebagai warga negara.

Berdasarkan uraian tersebut di atas, aspek pertanahan dan penataan ruang sangat perlu dan mutlak dipertimbangkan, karena tanah merupakan salah satu sumber daya kegiatan penduduk yang dapat di nilai sifat, keadaan, proses, dan penggunaannya. Hal tersebut sesuai dengan apa yang diungkapkan oleh Firey yang menyatakan: ${ }^{15}$ Tanah dapat menunjukkan pengaruh budaya yang besar dalam adaptasi ruang, dan selanjutnya dikatakan ruang dapat merupakan lambang bagi nilai-nilai sosial (misalnya penduduk sering memberi nilai sejarah yang besar kepada sebidang tanah).

Relevansi uraian di atas dengan implementasi Visi Kabupaten Sukabumi adalah dengan Kabupaten Sukabumi yang religius, maka diharapkan segala tingkah laku perbuatan selalu dilandaskan dengan keimanan, ilmu, dan amal. Sehingga, pentingnya pertanahan tidak disalah artikan dengan "siapa kuat dia yang menang" yang punya "duit" bisa membeli "semau"nya. Dengan tidak memperhatikan penataan ruang, kepentingan umum, nilai sosial dan kelestarian lingkungan hidup. Artinya dengan religius membuat perilaku yang tidak "melulu" berfikir yang “yang penting saya untung”. Kabupaten Sukabumi yang mandiri, artinya potensi yang dimiliki Kabupaten Sukabumi terutama di bidang pertanahan, harus bisa di optimalkan untuk kesejahteraan masyarakat lokal. Pemanfaatan lahan yang telah ditentukan oleh penataan ruang harus pro terhadap rakyat. Teringat UUD 1945 Pasal 33 ayat (3) yang menyebutkan Bumi dan air dan kekayaan alam yang terkandung didalamnya dikuasai oleh negara dan dipergunakan untuk sebesar-besar kemakmuran rakyat. Kabupaten Sukabumi mampu mendaya gunakan dan memaksimalkan potensi yang dimiliki sehingga menjadi daerah yang tangguh dan kompetitif. Yaitu dengan kebijakan pertanahan dan tata ruang.

Selanjutnya, Relevansi uraian di atas dengan implementasi Misi Kabupaten Sukabumi adalah:

a. Meningkatkan kemandirian ekonomi masyarakat berbasis ekonomi lokal melalui bidang agribisnis, pariwisata dan industri yang berwawasan.

15 Firey, dalam Asep Warlan Yusuf, Pranata Pembangunan, Bahan Kuliah Universitas Katolik Parahyangan, Bandung, 1997, hlm. 87. 
Hal ini sangat perlu dukungan kesediaan pertanahan dan penataan ruang yang baik sehingga masyarakat dapat meningkatkan kemandirian berbasis ekonomi lokal melalui bidang agribisnis, pariwisata dan industri yang berwawasan, yang bertujuan untuk kesejahteraan masyarakat.

b. Mewujudkan Sumber Daya Manusia yang berdaya saing dan religius.

Hal ini perlu di dukung dengan ketersediaan lahan tanah yang dapat mewujudkan sumber daya manusia yang berdaya saing dan religius, serta penataan ruang pusatpusat pendidikan, dan keagamaan.

c. Mewujudkan tata kelola pemerintahan yang bersih dan profesional.

d. Peran pertanahan dan tat ruang sangat perlu terlebih kesediaan lahan untuk sarana prasarana aparatur pemerintahan dalam melayani pelayanan publik agar tercapai tata kelola pemerintahan yang bersih dan profesional.

e. Optimalisasi pelayanan kesehatan, pendidikan, dan infrastruktur daerah.

Pembangunan pelayanan kesehatan, pendidikan, dan infrastruktur daerah harus perlu dilakukan agar semakin optimal dalam meningkatkan konektivitas antar wilayah dan pertumbuhan ekonomi masyarakat.

Hal tersebut di atas sangat perlu dilakukan kebijakan diwilayah pertanahan dan tata ruang yaitu:

a. Pelayanan Penerbitan Rekomendasi Harus Memperhatikan Status Tanah/Tata Ruang.

Aparatur Pemerintah Daerah harus secara cermat dalam melakukan tugasnya. Undang-Undang Republik Indonesia Nomor 5 Tahun 2014 tentang Aparatur Sipil Negara pasal 2 penyelenggaraan kebijakan dan manajemen ASN berdasarkan pada asas: 1. Kepastian hukum, artinya kelalaian dapat mengakibatkan suatu permasalahan dan ketidak pastian hukum. Di Dinas Pertanahan dan Tata Ruang yang memiliki kewenangan dalam memberikan rekomendasi, harus memperhatikan status tanah/tata ruang yang ada. Identifikasi dan tinjauan lapangan perlu untuk menentukan keluar/tidaknya rekmendasi agar berkepastian hukum untuk dilanjutkan ke perijinan.

b. Mediasi Penyelesaian Sengketa Tanah;

Dalam klausul menimbang pada huruf a Undang-Undang Republik Indonesia Nomor 5 Tahun 2014 Tentang Aparatur Sipil Negara, bahwa dalam rangka pelaksanaan cita-cita bangsa dan mewujudkan tujuan negara sebagaimana tercantum dalam pembukaan Undang-Undang Dasar Negara Republik Indonesia Tahun 1945, 
perlu dibangun aparatur sipil negara yang memiliki integritas, profesional, netral dan bebas dari intervensi politik, bersih dari praktik korupsi, kolusi, dan nepotisme, serta mampu menyelenggarakan pelayanan publik bagi masyarakat dan mampu menjalankan peran sebagai unsur perekat persatuan dan kesatuan bangsa berdasarkan Pancasila dan Undang-Undang Dasar Negara Republik Indonesia Tahun 1945.

Dalam hal ini, Dinas Pertanahan dan tata Ruang tidak luput dari suatu permasalahan yang melibatkan masyarakat. Konflik sengketa tanah seringkali muncul, dan kehadiran pemerintah diharapkan dapat menyelesaikan sengketa. Dengan ASN memiliki kewajiban mampu menyelenggarakan pelayanan publik bagi masyarakat dan mampu menjalankan peran sebagai unsur perekat persatuan dan kesatuan bangsa berdasarkan Pancasila dan Undang-Undang Dasar Negara Republik Indonesia Tahun 1945. Maka peran serta menjadi Mediasi penyelesaian sengketa tanah menjadi penting.

c. Pengamanan Tanah-Tanah Milik Pemerintah Daerah;

Perencanaan pembangunan daerah pada prinsipnya bertujuan mengintegrasikan rencana tata ruang wilayah dengan rencana pembangunan daerah. Dalam kaitan itu, penyusunan RPJMD harus berpedoman pada RTRW. Oleh karena itu, diperlukan kegiatan penelaahan RTRW untuk menjamin agar arah kebijakan dalam RPJMD selaras dengan, atau tidak menyimpang dari arah kebijakan RTRW. ${ }^{16}$

Namun yang perlu dipastikan semua tanah-tanah milik pemerintah daerah harus ada "pengamanan" tentang status tanah, jangan sampai adanya yang menggugatdari suatu individu atau kelompok terhadap tanah-tanah milik pemerintah daerah. Serta ironisnya lagi jika tanah-tanah milik pemerintah daerah tidak beralaskan hukum yang kuat, lalu ada yang menggugat dan penggugat menang. Dinas Pertanahan dan Tata Ruang bertugas untuk memastikan pengamanan tanah-tanah milik pemerintah daerah guna optimalisasi aparatur pemerintah daerah yang profesional dalam mendorong percepatan peningkatan kualitas pelayanan publik.

d. Alih Fungsi Lahan Pertanian;

Di era moderenitas ini, penulis mengamati ada yang menjadi perhatian bersama, yaitu:

16 Peraturan Daerah Kabupaten Sukabumi Nomor 4 Tahun 2016.....Op.Cit, hlm. 14 
1) Jumlah penduduk;

2) Jumlah kebutuhan pangan.

Dari ke dua hal tersebut di atas, maka tidak dapat dibendung laju pertumbuhan/kebutuhannya. Dengan semakin banyak penduduk maka berimplikasi dengan jumlah kebutuhan pangan. Pertanyaan besarnya adalah, apakah tercukupi luas wilayah tanah untuk pertanian? Aparatur Pemerintah Daerah bertanggungjawab atas ketersediaan lahan pertanian itu. Dengan acuan RPJMD selaras dengan, atau tidak menyimpang dari arah kebijakan RTRW, serta kebijakan lainnya untuk mengatasi alih fungsi lahan pertanian.

e. Penertiban Tanah-Tanah Eks HGU yang Terlantar.

Potensi pemanfaatan lahan untuk produksi/budidaya di Kabupaten Sukabumi sangat besar. Pemanfaatan lahan di Kabupaten Sukabumi dapat terlihat dari pola penggunaan lahan yang didominasi oleh kegiatan pertanian, perkebunan, kehutanan dan perikanan air tawar $(78,24 \%)$. Sementara sisanya adalah lahan terbangun yang meliputi perumahan/pemukiman, perkantoran serta industri/pabrik. Luasnya potensi lahan yang dapat dimanfaatkan memerlukan penataan dan pengendalian sesuai dengan peruntukan pemanfaatan ruang sebagaimana tertuang di dalam Rencana Tata Ruang Wilayah (RTRW) Kabupaten Sukabumi agar tidak terjadi inkonsistensi pemanfaatan ruang. ${ }^{17}$ Namun tidak di pungkiri di Kabupaten Sukabumi juga terdapat tanah-tanah eks HGU. Tanah-tanah ini harus memiliki kepastian hukum guna status tanah dapat diperuntukkan sebagaimana mestinya. Dinas Pertanahan dan Tata Ruang berkewajiban untuk Penertiban tanah-tanah eks HGU yang terlantar.

f. Peningkatan Kualitas Sdm Bidang Pertanahan dan Tata Ruang.

Dalam klausul menimbang pada huruf b Undang-Undang Republik Indonesia Nomor 5 Tahun 2014 tentang Aparatur Sipil Negara, bahwa pelaksanaan manajemen aparatur sipil negara belum berdasarkan pada perbandingan antara kompetensi dan kualifikasi yang diperlukan oleh jabatan dengan kompetensi dan kualifikasi yang dimiliki calon dalam rekrutmen, pengangkatan, penempatan, dan promosi pada jabatan sejalan dengan tata kelola pemerintahan yang baik. Berkenaan dengan hal ini maka perlu dilakukan peningkatan kualitas sdm bidang pertanahan dan tata ruang dengan mengadakan tugas belajar, seminar, diklat, bimtek, dll.

17 Ibid., hlm 25. 
g. Fungsionalisasi Regulasi Pertanahan dan Tata Ruang.

Kabupaten Sukabumi setidaknya telah memiliki:

1) Peraturan Daerah Kabupaten Sukabumi Nomor 13 Tahun 2009 tentang Rencana Pembangunan Jangka Panjang Daerah Kabupaten Sukabumi tahun 2005-2025;

2) Peraturan Daerah Kabupaten Sukabumi Nomor 22 Tahun 2012 tentang Rencana Tata Ruang Wilayah Kabupaten Sukabumi Tahun 2012-2032;

3) Peraturan Daerah Kabupaten Sukabumi Nomor 4 Tahun 2016 tentang Rencana Pembangunan Jangka Menengah Daerah Kabupaten Sukabumi Tahun 2016-2021.

Dari ke tiga contoh peraturan pemerintah daerah tersebut perlu adanya pengkajian dan evaluasi terhadap implementasi yang ada di masyarakat. Serta perlu dilakukan fungsionalisasi regulasi pertanahan dan tata ruang.

h. Perencanaan, Pemanfaatan Dan Pengawasan Dalam Bidang Pertanahan Dan Penataan Ruang.

Dinas Pertanahan dan Tata Ruang memiliki peran dalam "mengawal" perencanaan, pemanfaatan dan pengawasan dalam bidang rertanahan dan penataan ruang. Jangan sampai menjadi masalah dikemudian hari setelah dimanfaatkannya bidang pertanahan. Namun dalam hal pengawasan, pemerintah daerah perlu dukungan partisipasi masyarakat dalam memastikan pemanfaatan bidang pertanian sesuai dengan perencanaan dan penataan ruang yang sudah di atur dalam aturan yang berlaku.

i. Koordinasi Integrasi Dan Sinkronisasi Dengan Stakeholder Dalam Pelayanan Bidang Pertanahan Dan Penataan Ruang.

Undang-Undang Republik Indonesia Nomor 5 Tahun 2014 tentang Aparatur Sipil Negara pasal 3 menyatakan ASN sebagai profesi berlandaskan pada prinsip sebagai berikut:

1) nilai dasar;

2) kode etik dan kode perilaku;

3) komitmen, integritas moral, dan tanggung jawab pada pelayanan publik;

4) kompetensi yang diperlukan sesuai dengan bidang tugas;

5) kualifikasi akademik.

Dalam poin c sudah jelas bahwa prinsip komitmen, integritas moral, dan tanggung jawab pada pelayanan publik menjadi dasar dalam koordinasi integrasi dan sinkronisasi dengan stakeholder, khususnya dalam pelayanan bidang pertanahan dan penataan ruang. Karena tidak 
mungkin optimal Dinas Pertanahan dan Tata Ruang tanpa adanya koordinasi antar SKPD dan stakeholder, sekali lagi harus terciptanya super team dalam mewujudkan Kabupaten Sukabumi sesuai dengan Visi Misi-nya.

\section{SIMPULAN DAN SARAN}

\subsection{Kesimpulan.}

Dari uraian di atas maka mewujudkan aparatur pemerintah daerah yang profesional dalam mendorong percepatan peningkatan kualitas pelayanan publik melalui Dinas Pertanahan Dan Tata Ruang Kabupaten Sukabumi perlu:

1. Mengacu dalam Visi Misi Kabupaten Sukabumi secara optimal jika adanya kerjasama antar komponen yang berkepentingan;

2. Mengatasi potensi permasalahan yang timbul di Dinas Pertanahan dan Tata Ruang Kabupaten Sukabumi, yaitu:

a. Pelayanan penerbitan rekomendasi harus memperhatikan status tanah/tata ruang;

b. Mediasi penyelesaian sengketa tanah;

c. Pengamanan tanah-tanah milik pemerintah daerah;

d. Alih fungsi lahan pertanian;

e. Penertiban tanah-tanah eks HGU yang terlantar;

f. Peningkatan kualitas sdm bidang pertanahan dan tata ruang;

g. Fungsionalisasi regulasi pertanahan dan tata ruang;

h. Perencanaan, pemanfaatan dan pengawasan dalam bidang pertanahan dan penataan ruang;

i. Koordinasi integrasi dan sinkronisasi dengan stakeholder dalam pelayanan bidang pertanahan dan penataan ruang;

\subsection{Saran.}

1. Dalam menyikapi berbagai potensi permasalahan yang ada, selain kerja sama/super team maka sarana dan prasarana, keuangan harus juga tersedi/memadai;

2. Mengingat Dinas ini adalah pembentukan baru, maka perlu adaptasi dalam melaksanakan fungsi serta sentralnya kewenangan yang dimiliki yaitu tentang pertanahan dan tata ruang. Dengan demikian saran untuk mengatasi potensi permasalahan yang akan di hadapi sebagai berikut: 
a. Pemberian pelayanan rekomendasi, aparatur pemerintah di Dinas Pertanahan dan Tata Ruang harus memperhatikan status tanah/tata ruang dan melakukan survei/tinjauan lapangan;

b. Aparatur Pemerintah di Dinas Pertanahan dan Tata Ruang memiliki kemampuan dalam memfasilitasi mediasi penyelesaian sengketa tanah. Artinya penyelesaian non penal lebih menjadi solusi. Karena musyawarah merupakan asas kekeluargaan di masyarakat;

c. Aparatur Pemerintah di Dinas Pertanahan dan Tata Ruang melakukan pendataan ulang kembali, menginfentarisir dan menghimpun data-data pendukung untuk pengamanan tanah-tanah milik pemerintah daerah. Terutama tanah-tanah milik pemerintah daerah yang tidak memiliki alas hukum/sertifikat, karena potensi untuk menjadi objek sengketa tanah.

d. Sebaiknya alih fungsi pertanian harus menjadi perhatian, karena ketahanan pangan guna memenuhi kebutuhan masyarakat. oleh sebab itu penanganan haruslah selektif.

e. Dinas Pertanahan dan Tata Ruang perlu melakukan penertiban tanah-tanah eks HGU yang terlantar, agar kepastian hukum serta potensi sengketa dapat diminimalisir.

f. Mewujudkan aparatur pemerintah daerah yang profesional dalam mendorong percepatan peningkatan kualitas pelayanan publik melalui dinas pertanahan dan tata ruang Kabupaten Sukabumi, tidak lain dengan peningkatan kualitas sdm bidang pertanahan dan tata ruang. Sdm haruslah yang mampu untuk memberikan pelayanan secara optimal, mampu menyelesaikan permasalahan yang ada;

g. Sebaiknya regulasi-regulasi yang sudah ada mengenai pertanahan dan tata ruang di evaluasi, lalu di Fungsionalisasikan regulasi pertanahan dan tata ruang tersebut, atau bisa merevisi regulasi, bahkan membuat regulasi yang baru.

h. SDM di Dinas Pertanahan Dan Tata Ruang harus benar-benar melakukan perencanaan, pemanfaatan dan pengawasan dalam bidang pertanahan dan penataan ruang, guna memastikan pertanahan dimanfaatkan sebagaimana mestinya sesuai dengan perencanaan. Pengawasan dapat dilakukan secara berkelanjutan dan melakukan sidak ke lokasi. 
i. Koordinasi integrasi dan sinkronisasi dengan stakeholder dalam pelayanan bidang pertanahan dan penataan ruang menjadi sangat penting mengingat Dinas Pertanahan dan Tata Ruang tidak dapat melaksanakan sendiri. Dengan demikian perlu diadakan pertemuan rutin untuk koordinasi serta singkronisasi untuk membahas dan evaluasi dalam pelayanan bidang pertanahan dan penataan ruang.

\section{DAFTAR PUSTAKA}

A.M Yunus Wahid, Pengantar Hukum Tata Ruang, Kencana Prenada Group, Jakarta, 2014.

Firey, dalam Asep Warlan Yusuf, Pranata Pembangunan, Bahan Kuliah Universitas Parahyangan, 1997.

Juniarso Ridwan dan Achmad Sodik, Hukum tata Ruang (dalam konsep kebijakan otonomi daerah), Nuansa, Bandung, 2013.

Lawrence M. Friedman, American Law, (New York-London), W.W. Norton \& Company, 1984.

Mulyono Sadyohutomo, Tata Guna Tanah dan Penyerasian Tata Ruang, Pustaka Pelajar, Yogyakarta, 2016.

Safri Nugraha, dkk, Hukum Administrasi Negara, Editor: Sri Mamudi, Center for Law and Good Governance Studies (CLGS) Fakultas Hukum Universitas Indonesia, Jakarta, 2007.

Undang-Undang Dasar Negara Republik Indonesia Tahun 1945.

Undang-Undang Republik Indonesia Nomor 5 Tahun 2014 tentang Aparatur Sipil Negara.

Undang-Undang Nomor 15 Tahun 2015 tentang Pemilukada Serentak.

Peraturan Daerah Kabupaten Sukabumi Nomor 4 Tahun 2016 tentang Rencana Pembangunan Jangka Menengah Daerah Kabupaten Sukabumi Tahun 2016-2021.

Peraturan Daerah Kabupaten Sukabumi Nomor 13 Tahun 2009 tentang Rencana Pembangunan Jangka Panjang Daerah Kabupaten Sukabumi tahun 2005-2025.

Peraturan Daerah Kabupaten Sukabumi Nomor 22 Tahun 2012 tentang Rencana Tata Ruang Wilayah Kabupaten Sukabumi Tahun 2012-2032. 